\title{
SUBTASK 7.4 - POWDER RIVER BASIN SUBBITUMINOUS COAL-BIOMASS COGASIFICATION TESTING IN A TRANSPORT REACTOR
}

Final Report

(for the period August 1, 2007, through March 31, 2009)

Prepared for:

AAD Document Control

U.S. Department of Energy

National Energy Technology Laboratory

626 Cochrans Mill Road

PO Box 10940, MS 921-107

Pittsburgh, PA 15236-0940

Cooperative Agreement No. DE-FC26-98FT40320

Project Manager: Ronald Breault

Prepared by:

Michael L. Swanson Daniel A. Laudal

Energy \& Environmental Research Center University of North Dakota 15 North 23rd Street, Stop 9018

Grand Forks, ND 58202-9018 


\section{EERC DISCLAIMER}

LEGAL NOTICE This research report was prepared by the Energy \& Environmental Research Center (EERC), an agency of the University of North Dakota, as an account of work sponsored by the U.S. Department of Energy (DOE). Because of the research nature of the work performed, neither the EERC nor any of its employees makes any warranty, express or implied, or assumes any legal liability or responsibility for the accuracy, completeness, or usefulness of any information, apparatus, product, or process disclosed or represents that its use would not infringe privately owned rights. Reference herein to any specific commercial product, process, or service by trade name, trademark, manufacturer, or otherwise does not necessarily constitute or imply its endorsement or recommendation by the EERC.

\section{DISCLAIMER}

This report was prepared as an account of work sponsored by an agency of the United States Government. Neither the United States Government, nor any agency thereof, nor any of their employees makes any warranty, express or implied, or assumes any legal liability or responsibility for the accuracy, completeness, or usefulness of any information, apparatus, product, or process disclosed or represents that its use would not infringe privately owned rights. Reference herein to any specific commercial product, process, or service by trade name, trademark, manufacturer, or otherwise does not necessarily constitute or imply its endorsement, recommendation, or favoring by the United States Government or any agency thereof. The views and opinions of authors expressed herein do not necessarily state or reflect those of the United States Government or any agency thereof.

This report is available to the public from the National Technical Information Service, U.S. Department of Commerce, 5285 Port Royal Road, Springfield, VA 22161; phone orders accepted at (703) 487-4650.

\section{ACKNOWLEDGMENTS}

This report was prepared with the support of the U.S. Department of Energy (DOE) National Energy Technology Laboratory Cooperative Agreement No. DE-FC26-98FT40320. However, any opinions, findings, conclusions, or recommendations expressed herein are those of the authors(s) and do not necessarily reflect the views of DOE. 


\title{
SUBTASK 7.4 - POWDER RIVER BASIN SUBBITUMINOUS COAL-BIOMASS COGASIFICATION TESTING IN A TRANSPORT REACTOR
}

\begin{abstract}
The U.S. Department of Energy (DOE) National Energy Technology Laboratory Office of Coal and Environmental Systems has as its mission to develop advanced gasification-based technologies for affordable, efficient, zero-emission power generation. These advanced power systems, which are expected to produce near-zero pollutants, are an integral part of DOE's Vision 21 Program. DOE has also been developing advanced gasification systems that lower the capital and operating costs of producing syngas for chemical production. A transport reactor has shown potential to be a low-cost syngas producer compared to other gasification systems since its high-throughput-per-unit cross-sectional area reduces capital costs. This work directly supports the Power Systems Development Facility utilizing the Kellogg Brown and Root transport reactor located at the Southern Company Services Wilsonville, Alabama, site.
\end{abstract}

Over 3600 hours of operation on 17 different coals ranging from bituminous to lignite along with a petroleum coke has been completed to date in the pilot-scale transport reactor development unit (TRDU) at the Energy \& Environmental Research Center (EERC). The EERC has established an extensive database on the operation of these various fuels in both air- and oxygen-blown modes utilizing a pilot-scale transport reactor gasifier. This database has been useful in determining the effectiveness of design changes on an advanced transport reactor gasifier and for determining the performance of various feedstocks in a transport reactor.

The effects of different fuel types on both gasifier performance and the operation of the hot-gas filter system have been determined. It has been demonstrated that corrected fuel gas heating values ranging from 90 to $130 \mathrm{Btu} / \mathrm{scf}$ have been achieved in air-blown mode, while heating values up to $230 \mathrm{Btu} / \mathrm{scf}$ on a dry basis have been achieved in oxygen-blown mode. Carbon conversions up to $90 \%$ have also been obtained and are highly dependent on the oxygencoal ratio. Higher-reactivity (low-rank) coals appear to perform better in a transport reactor than the less reactive bituminous coals. Factors that affect TRDU product gas quality appear to be coal type, temperature, and oxygen/fuel ratios.

During this series of tests, a previously tested baseline Powder River Basin (PRB) subbituminous coal from the Peabody Energy North Antelope Rochelle Mine near Gillette, Wyoming was mixed with $20 \mathrm{wt} \%$ biomass. Two types of biomass were used-wood waste and switchgrass. Gas and particulate sampling at several locations in the riser provided information on coal devolatilization and cracking chemistry as a function of residence time, transport gas, and mode of operation. The goal of these tests was to compare the operating data and sample chemistry of the coal-biomass mixture to the PRB coal, with a focus on Fischer-Tropsch coalto-liquid production in oxygen-blown mode. Data are to be provided to DOE to determine kinetic rates of devolatilization and tar cracking. 


\section{TABLE OF CONTENTS}

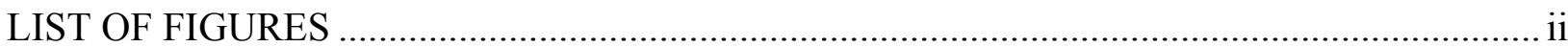

LIST OF TABLES ........................................................................................................... ii

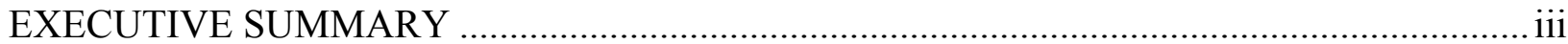

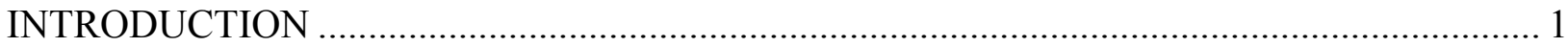

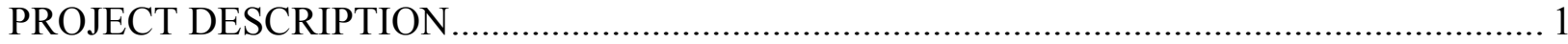

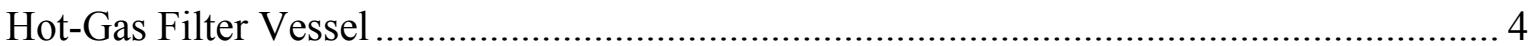

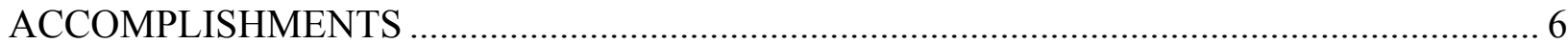

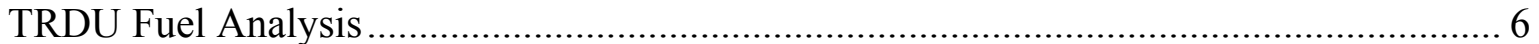

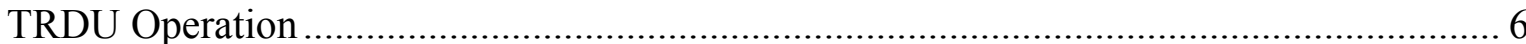

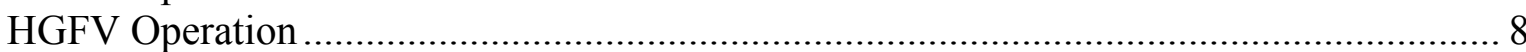

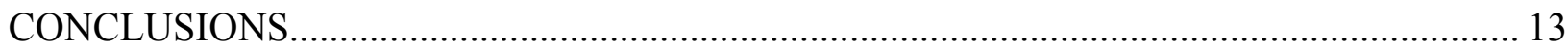

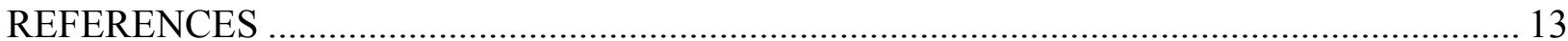




\section{LIST OF FIGURES}

1 TRDU, hot-gas filter vessel (HGFV), and thermal oxidizer in EERC gasification

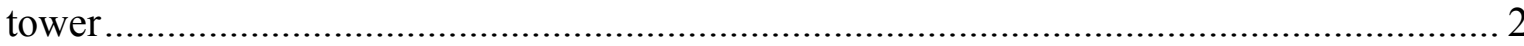

2 Schematic of filter vessel design with internal refractory, tubesheet, and shroud .............. 5

3 Particle-size distribution for filter vessel and standpipe samples collected during

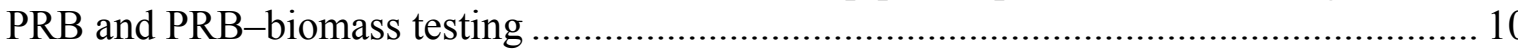

4 Comparative histogram of ash chemistry data for samples taken at filter vessel ............. 12

5 Comparative histogram of ash chemistry data for samples taken from standpipe............ 12

\section{LIST OF TABLES}

1 Summary of TRDU Design and Operation on the Design Coal ................................... 3

2 Design Criteria and Actual Operating Conditions for the Pilot-Scale HGFV ................... 4

3 Proximate-Ultimate, XRF, and Heating Value for Feedstocks ................................... 7

4 Typical TRDU Operating Conditions and Product Gas Compositions............................. 8

5 Best-Case Gasification Operating Conditions.......................................................... 9

$6 \quad$ XRF Ash Analysis of Standpipe and Filter Vessel Ash Samples .................................. 11 


\section{SUBTASK 7.4 - POWDER RIVER BASIN SUBBITUMINOUS COAL-BIOMASS COGASIFICATION TESTING IN A TRANSPORT REACTOR}

\section{EXECUTIVE SUMMARY}

The U.S. Department of Energy (DOE) National Energy Technology Laboratory Office of Coal and Environmental Systems has as its mission to develop advanced gasification-based technologies for affordable, efficient, zero-emission power generation. These advanced power systems, which are expected to produce near-zero pollutants, are an integral part of DOE's Vision 21 Program. DOE has also been developing advanced gasification systems that lower the capital and operating costs of producing syngas for chemical production. A transport reactor has shown potential to be a low-cost syngas producer compared to other gasification systems since its high-throughput-per-unit cross-sectional area reduces capital costs. This work directly supports the Power Systems Development Facility utilizing the Kellogg Brown and Root transport reactor located at the Southern Company Services Wilsonville, Alabama, site.

During this series of tests, a previously tested baseline Powder River Basin (PRB) subbituminous coal from the Peabody Energy North Antelope Rochelle Mine near Gillette, Wyoming, was mixed with $20 \mathrm{wt} \%$ biomass. Two types of biomass were used-wood waste and switchgrass. Gas and particulate sampling at several locations in the riser provided information on coal devolatilization and cracking chemistry as a function of residence time, transport gas, and mode of operation. The goal of these tests was to compare the operating data and sample chemistry of the coal-biomass mixture to the PRB coal, with a focus on Fischer-Tropsch (FT) coal-to-liquids (CTL) production in oxygen-blown mode, with data being provided to DOE to determine kinetic rates of devolatilization and tar cracking.

Both wood waste and switchgrass were successfully cofed and gasified in a transport reactor gasifier at approximately a $20 \mathrm{wt} \%$ ratio, resulting in smooth operation with good syngas heating value, very high carbon conversion, and no operational issues such as bed agglomeration. Surprisingly few coal-biomass feed trips were encountered during the testing while utilizing the current coal feed system. Initial shakedown testing suggested that in the 25 to $30 \mathrm{wt} \%$ range, coal feed trips would be much more problematic, which led to the selection of the $20 \mathrm{wt} \%$ feed ratio. Since the production of FT liquids from coal has a higher carbon footprint than liquid production from petroleum, this successful demonstration testing suggests that cofeeding biomass with coal to reduce the carbon footprint of the FT liquids production plant to below those obtained from a coal-only plant is certainly feasible.

Successful extraction of gas and solid samples from five sample locations in the transport reactor development unit was accomplished using a PRB coal and PRB-biomass mixtures. The data suggest very little coal backmixing in the mixing zone. With increasing residence time, aliphatics concentration decreased, while aromatics concentration increased slightly. Higher gasifier temperatures resulted in lower methane and aliphatics concentrations and higher aromatics concentrations. The sampling also suggests that significantly higher levels of organic species were seen in the lower regions of the riser as a result of the high volatile matter present in the biomass. However, by the exit of the transport reactor, the organic concentrations were very similar between the coal-only tests and the biomass cofeeding tests. 


\section{SUBTASK 7.4 - POWDER RIVER BASIN SUBBITUMINOUS COAL-BIOMASS COGASIFICATION TESTING IN A TRANSPORT REACTOR}

\section{INTRODUCTION}

The goal of the advanced high-temperature, high-pressure transport gasification program at the Energy \& Environmental Research Center (EERC) is to demonstrate acceptable hydrodynamic and gasification performance of the transport reactor development unit (TRDU) under a variety of operating conditions and using a wide range of fuels. Current objectives are focused on understanding and improving the operation of the transport reactor gasifier itself under both air- and oxygen-blown conditions. Recently, in order to better understand the coal devolatilization and cracking chemistry occurring in the riser of a transport reactor, gas and solids sampling directly from the riser and the filter outlet has been accomplished. A secondary objective of the program is to demonstrate acceptable performance of hot-gas filter elements on the hot, dust-laden fuel gas stream coming from the pilot-scale system prior to long-term demonstration tests.

In order to extend the database of fuels tested, a previously tested baseline Powder River Basin (PRB) subbituminous coal from the Peabody Energy North Antelope Rochelle Mine near Gillette, Wyoming, was mixed with $20 \mathrm{wt} \%$ biomass. Two types of biomass were used-wood waste and switchgrass. The goal of these tests was to compare the operating data and sample chemistry of the coal-biomass mixture to the PRB coal, with a focus on Fischer-Tropsch (FT) coal-to-liquid (CTL) production in oxygen-blown mode. Data were provided to DOE to determine kinetic rates of devolatilization and tar cracking.

\section{PROJECT DESCRIPTION}

The pilot-scale TRDU has an exit gas temperature of up to $980^{\circ} \mathrm{C}\left(1800^{\circ} \mathrm{F}\right)$, a gas flow rate of $325 \mathrm{scfm}\left(0.153 \mathrm{~m}^{3} / \mathrm{s}\right)$, and an operating pressure of $120 \mathrm{psig}(9.3 \mathrm{bar})$. The TRDU system can be divided into three sections: the coal feed section, the TRDU, and the product recovery section. The TRDU proper, as shown in Figure 1, consists of a riser reactor with an expanded mixing zone at the bottom, a disengager, and a primary cyclone and standpipe. The standpipe is connected to the mixing section of the riser by an L-valve transfer line. All of the components in the system are refractory-lined and designed mechanically for 150 psig (11.4 bar) and an internal temperature of $1090^{\circ} \mathrm{C}\left(2000^{\circ} \mathrm{F}\right)$. Detailed design criteria and a comparison to actual operating conditions on the design coal are given in Table 1.

The premixed coal and biomass fed to the transport reactor can be admitted through three nozzles, which are at varying elevations. Two of these nozzles are located near the top of the

mixing zone (gasification mode), and the remaining one is near the bottom of the mixing zone (combustion mode). During operation of the TRDU, feed is admitted through only one nozzle at a time. The feed is measured by a revolutions-per-minute (rpm)-controlled metering auger. Oxidant is fed to the reactor through two pairs of nozzles at varying elevations within the mixing zone. 


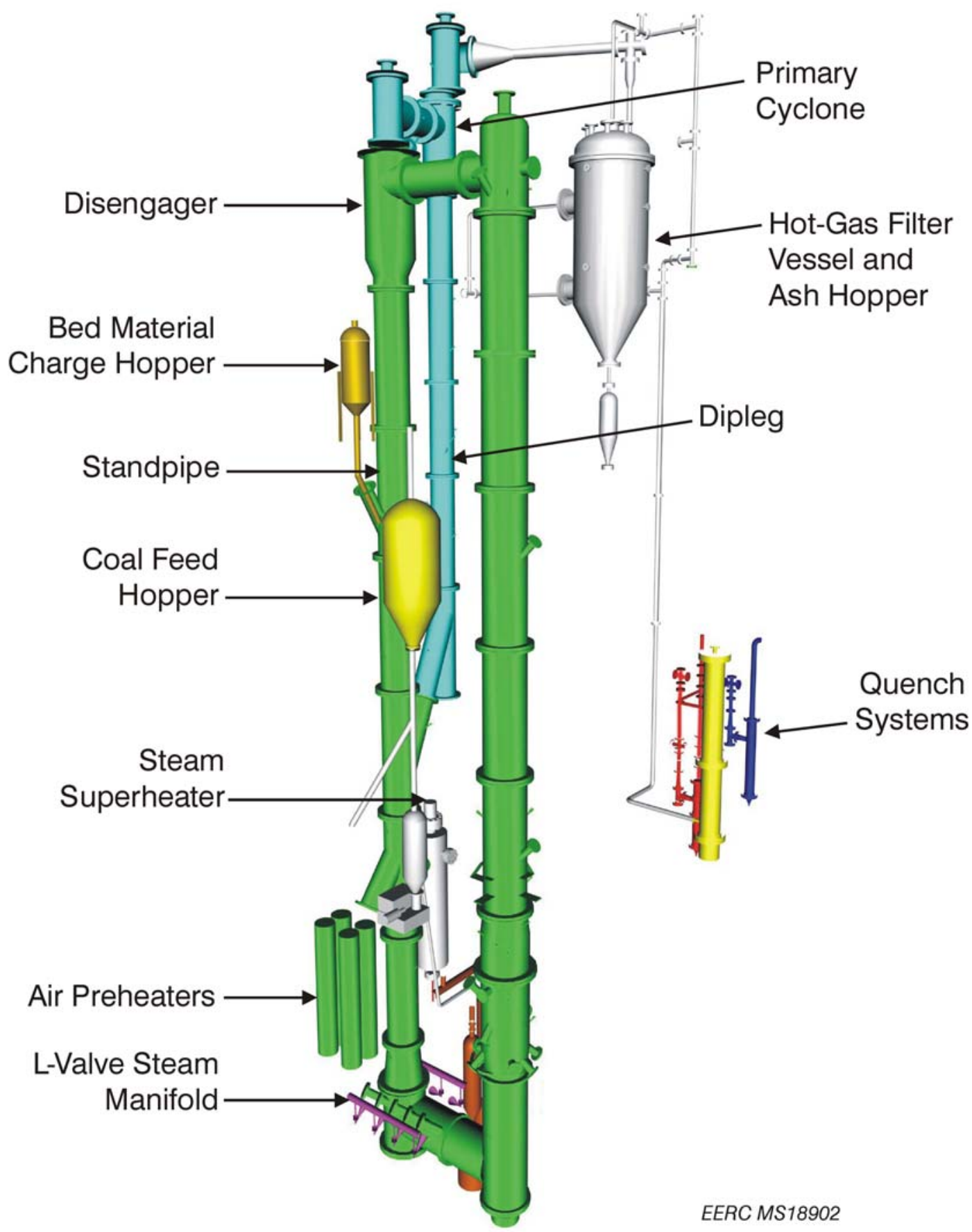

Figure 1. TRDU, hot-gas filter vessel (HGFV), and thermal oxidizer in EERC gasification tower. 
high heat losses, the fuel gas from the TRDU is of generally sufficient quality to sustain combustion in the thermal oxidizer without the requirement of supplemental fuel.

\section{Hot-Gas Filter Vessel}

This vessel is designed to handle all of the gas flow from the TRDU at its expected operating conditions. The vessel is approximately 48-in. i.d. $(121.9 \mathrm{~cm})$ and $185 \mathrm{in} .(470 \mathrm{~cm})$ long and is designed to handle gas flows of approximately $325 \mathrm{scfm}$ at temperatures up to $815^{\circ} \mathrm{C}$ $\left(1500^{\circ} \mathrm{F}\right)$ and pressures of $120 \mathrm{psig}(8.3 \mathrm{bar})$. The refractory has a 28 -in. $(71.1-\mathrm{cm})$ i.d. with a shroud diameter of approximately $22 \mathrm{in} .(55.9 \mathrm{~cm})$. The vessel is sized such that it could handle candle filters up to $2.0 \mathrm{~m}$ long; however, $1.5-\mathrm{m}$ iron aluminide metal candle filters were utilized in these reported gasification tests. Candle filters are 2.375 in. $(6 \mathrm{~cm})$ o.d. with a 4 -in. $(10.2-\mathrm{cm})$ center line-to-center line spacing. The filter design criteria are summarized in Table 2. A schematic of the filter system is shown in Figure 2.

The total number of candles that can be mounted in the current geometry of the HGFV tube sheet is 19 . This enables filter face velocities as low as $2.0 \mathrm{ft} / \mathrm{min}$ to be tested using $1.5-\mathrm{m}$ candles. Higher face velocities are achieved by using fewer candles. The majority of testing has been performed at a face velocity of approximately 4.0 to $4.5 \mathrm{ft} / \mathrm{min}$. These recent tests have utilized the sintered metal (iron aluminide) and Vitropore silicon carbon ceramic candles from Pall Advanced Separation Systems Corporation.

The ash letdown system consists of two sets of alternating high-temperature valves with a conical pressure vessel to act as a lock hopper. Additionally, a preheat natural gas burner attached to a lower inlet nozzle on the filter vessel can be used to preheat the filter vessel separately from the TRDU. The hot gas from the burner enters the vessel via a nozzle inlet separate from the dirty gas.

Table 2. Design Criteria and Actual Operating Conditions for the Pilot-Scale HGFV

\begin{tabular}{lcc}
\hline Operating Conditions & Design & Actual \\
\hline Inlet Gas Temperature & $540^{\circ} \mathrm{C}$ & $450^{\circ}-580^{\circ} \mathrm{C}$ \\
Operating Pressure & $150 \mathrm{psig}(10.3 \mathrm{bar})$ & $120 \mathrm{psig}(8.3 \mathrm{bar})$ \\
Volumetric Gas Flow & $325 \mathrm{scfm}\left(0.153 \mathrm{~m}^{3} / \mathrm{s}\right)$ & $350 \mathrm{scfm}\left(0.165 \mathrm{~m}^{3} / \mathrm{s}\right)$ \\
Number of Candles & $19(1 \mathrm{or} 1.5 \mathrm{~m})$ & $13(1 \mathrm{~m})$ \\
Candle Spacing & $4 \mathrm{in} . \Phi$ to $\Phi(10.2 \mathrm{~cm})$ & $4 \mathrm{in} . \Phi$ to $\Phi(10.2 \mathrm{~cm})$ \\
Filter Face Velocity & $2.5-10 \mathrm{ft} / \mathrm{min},(1.3$ to $2.3 \mathrm{~cm} / \mathrm{s})$ & $4.5 \mathrm{ft} / \mathrm{min},(2.3 \mathrm{~cm} / \mathrm{s})$ \\
Particulate Loading & $<10,000 \mathrm{ppmw}$ & $<38,000 \mathrm{ppmw}$ \\
Temperature Drop Across HGFV & $<30^{\circ} \mathrm{C}$ & $25^{\circ} \mathrm{C}$ \\
Nitrogen Backpulse System & up to $600 \mathrm{psig}$ & 250 to $350 \mathrm{psig}$ \\
Pressure & $(42 \mathrm{bar})$ & $(17$ to $24 \mathrm{bar})$ \\
Backpulse Valve Open Duration & up to $1 \mathrm{~s}$ & $1 / 4 \mathrm{~s}$ \\
\hline
\end{tabular}




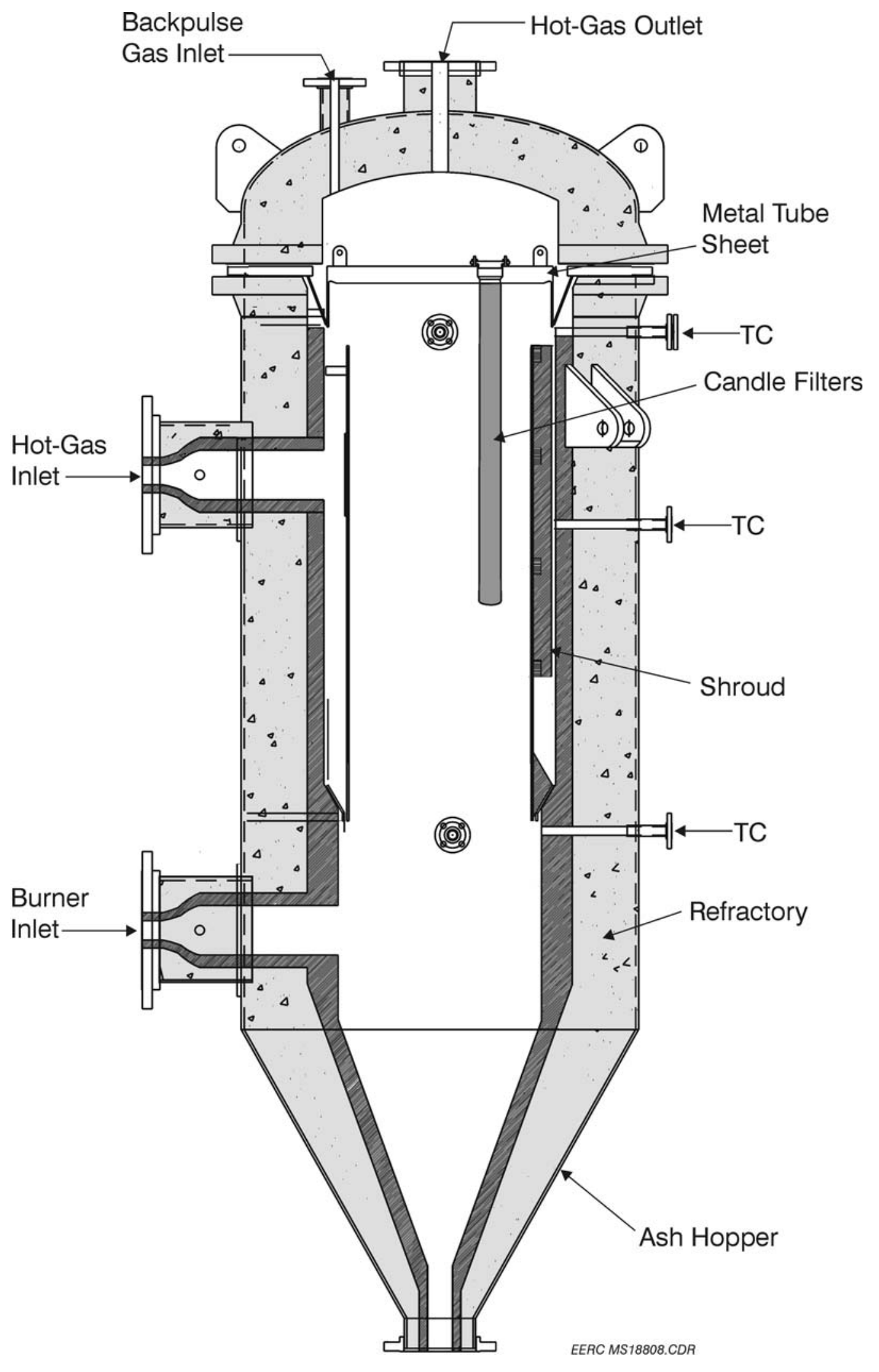

Figure 2. Schematic of filter vessel design with internal refractory, tubesheet, and shroud. 
The high-pressure nitrogen backpulse system is capable of backpulsing up to four sets of four or five candle filters with ambient-temperature nitrogen in a time-controlled sequence. The pulse length and volume of nitrogen displaced into the filter vessel are controlled by regulating the pressure (up to 600 psig [ 42 bar]) of the nitrogen reservoir and controlling the solenoid valve pulse duration. Figure 1 also shows the filter vessel location and process piping in the EERC gasifier tower. Lower operating filter temperatures around $260^{\circ} \mathrm{C}\left(500^{\circ} \mathrm{F}\right)$ were tested utilizing recent modifications that added extra heat exchange surface in order to operate the filter vessel at these lower temperatures. Most of the previous filter tests were completed in the $425^{\circ}-650^{\circ} \mathrm{C}$ $\left(800^{\circ}-1200^{\circ} \mathrm{F}\right)$ range. Ports for obtaining hot, high-pressure particulate and trace metal samples both upstream and downstream of the filter vessel are part of the filter system piping.

\section{ACCOMPLISHMENTS}

\section{TRDU Fuel Analysis}

The PRB subbituminous coal from the Rochelle Mine, which is similar to other PRB coals frequently tested in the TRDU, was sized to -10 mesh $(2000 \mu \mathrm{m})$ and mixed with $20 \mathrm{wt} \%$ biomass - wood waste or switchgrass. The biomass feedstocks were air-dried to less than 10\% moisture and hammer-milled through a 1/8-in. screen before being mixed with the PRB coal for testing. Table 3 shows the proximate, ultimate, HHV, and x-ray fluorescence (XRF) analyses of the PRB coals, the two types of biomass, and the two coal-biomass mixtures.

\section{TRDU Operation}

A total of 29 successful test campaigns have been completed to date, with approximately 3600 hours of operation in gasification on several different fuels $(1,2)$. These fuels have ranged from less reactive bituminous coals and petcoke to the more reactive subbituminous and lignite coals. Operating temperatures have been varied from $815^{\circ}$ to $1050^{\circ} \mathrm{C}\left(1500^{\circ}\right.$ to $\left.1900^{\circ} \mathrm{F}\right)$, depending on the fuel reactivity and the fuel ash's propensity to agglomerate.

Previous testing of the PRB coal utilized only three test conditions, all in air-blown mode. However, in this series of testing, operation in both air- and oxygen-blown modes was employed. The first test condition utilized the PRB-wood mixture in air-blown mode with nitrogen as the transport gas. The next used the same feedstock and transport gas, but was performed in oxygen blown-mode. The final test using the PRB-wood mixture was performed in oxygen-blown mode using transport air. The final two conditions tested the PRB-switchgrass mixture with transport air in both oxygen- and air-blown mode. A detailed description of the typical operating conditions as well as the resulting product gas compositions is shown in Table 4.

Table 5 shows the best-case operating conditions. These were determined based on the conditions that produced the syngas with the highest heating value and carbon conversion. This scenario occurred when using transport air in oxygen-blown mode for both feedstocks. For the PRB-wood feedstock, a heating value of $113 \mathrm{Btu} / \mathrm{scf}$ and carbon conversion of $94.8 \%$ were achieved. The PRB-switchgrass feedstock produced a heating value of $100 \mathrm{Btu} / \mathrm{scf}$, with a carbon conversion of $97.8 \%$. Corrected heating values are also shown in Table 5, which adjust for a dry gas with no theoretical heat losses. 
Table 3. Proximate-Ultimate, XRF, and Heating Value for Feedstocks

\begin{tabular}{|c|c|c|c|c|c|}
\hline & PRB & $\begin{array}{l}\text { Wood } \\
\text { Waste }\end{array}$ & Switchgrass & PRB-Wd ${ }^{2}$ & PRB-SG ${ }^{3}$ \\
\hline \multicolumn{6}{|c|}{ Proximate Analysis, as run, wt $\%$} \\
\hline Moisture & 23.4 & 6.3 & 5.4 & 23.7 & 19.9 \\
\hline Volatile Matter & 33.82 & 80.83 & 69.78 & 34.38 & 35.72 \\
\hline Fixed Carbon & 37.28 & 2.69 & 17.03 & 35.02 & 37.43 \\
\hline Ash & 5.49 & 0.19 & 7.79 & 6.9 & 6.95 \\
\hline \multicolumn{6}{|c|}{ Ultimate Analysis, $\mathrm{MF}^{1}$, wt $\%$} \\
\hline Carbon & 67.49 & 48.6 & 44.04 & 49.77 & 50.31 \\
\hline Hydrogen & 4.68 & 6 & 5.71 & 6.41 & 6.26 \\
\hline Nitrogen & 1.18 & 0.3 & 1.22 & 0.13 & 1.04 \\
\hline Sulfur & 0.31 & 0.01 & 0.03 & 0.22 & 0.28 \\
\hline Oxygen & 19.18 & 44.89 & 40.78 & 36.58 & 35.16 \\
\hline Ash & 7.17 & 0.2 & 8.23 & 6.9 & 6.95 \\
\hline \multicolumn{6}{|l|}{$\mathrm{XRF}, \mathrm{wt} \%$} \\
\hline $\mathrm{Si}$ & 18.10 & 4.83 & 47.80 & 20.42 & 27.34 \\
\hline $\mathrm{Al}$ & 12.50 & 1.23 & 0.00 & 12.20 & 10.50 \\
\hline $\mathrm{Fe}$ & 10.10 & 1.77 & 0.31 & 6.46 & 5.60 \\
\hline Ti & 1.30 & 0.17 & 0.06 & 1.19 & 1.03 \\
\hline $\mathrm{P}$ & 0.70 & 1.91 & 1.95 & 0.76 & 1.15 \\
\hline $\mathrm{Ca}$ & 36.50 & 56.33 & 8.26 & 38.53 & 32.30 \\
\hline $\mathrm{Mg}$ & 10.50 & 8.64 & 4.90 & 10.28 & 8.49 \\
\hline $\mathrm{Na}$ & 1.80 & 3.40 & 0.65 & 1.36 & 1.05 \\
\hline $\mathrm{K}$ & 0.60 & 20.26 & 35.08 & 0.85 & 4.21 \\
\hline S & 7.80 & 1.44 & 0.99 & 7.94 & 8.33 \\
\hline $\begin{array}{l}\text { Higher Heating Value, } \\
\text { as received, Btu/lb }\end{array}$ & 8770 & 7721 & 7317 & 8280 & 8672 \\
\hline \multirow{2}{*}{\multicolumn{6}{|c|}{$\begin{array}{l}{ }^{1} \text { Moisture-free. } \\
{ }^{2} \text { Wood. }\end{array}$}} \\
\hline & & & & & \\
\hline${ }^{3}$ Switchgrass. & & & & & \\
\hline
\end{tabular}

Oxygen-blown operation requires the addition of considerable excess steam to maintain the reactor temperatures below the temperature where ash deposition and agglomeration of the circulating ash material become a problem. Carbon conversion seems to be primarily dependent on the ratio of the weight of oxygen fed to the weight of the maf coal fed regardless of the form by which the oxygen was fed (air versus oxygen).

In general, operation on the more reactive low-rank western coals has displayed higher carbon conversions and product gas heating values even when operating at lower reactor temperatures than comparable bituminous coal tests. 
Table 4. Typical TRDU Operating Conditions and Product Gas Compositions

\begin{tabular}{|c|c|c|c|c|c|c|c|}
\hline Test & $\begin{array}{c}\text { PRB } \\
\text { Air- } \\
\text { Blown }\end{array}$ & $\begin{array}{c}\text { PRB } \\
\text { Air-Blown }\end{array}$ & $\begin{array}{l}\text { PRB-Wd } \\
\text { Air-Blown }\end{array}$ & $\begin{array}{c}\text { PRB-Wd } \\
\mathrm{O}_{2^{-}} \\
\text {Blown }\end{array}$ & $\begin{array}{l}\mathrm{PRB}-\mathrm{Wd} \\
\mathrm{O}_{2} \text {-Blown }\end{array}$ & $\begin{array}{l}\text { PRB-SG } \\
\mathrm{O}_{2} \text {-Blown }\end{array}$ & $\begin{array}{c}\text { PRB-SG } \\
\text { Air- } \\
\text { Blown }\end{array}$ \\
\hline Transport Gas & $\mathrm{N}_{2}$ & Air & $\mathrm{N}_{2}$ & $\mathrm{~N}_{2}$ & Air & Air & Air \\
\hline Gasifier Temp.,${ }^{\circ} \mathrm{C}$ & 901 & 898 & 889 & 877 & 937 & 918 & 910 \\
\hline $\begin{array}{l}\text { Feedstock Feed } \\
\text { Rate, } 1 \mathrm{~b} / \mathrm{hr}\end{array}$ & 338 & 355 & 425 & 389 & 385 & 376 & 438 \\
\hline Airflow, lb/hr & 1160 & 1035 & 986 & 115 & 251 & 248 & 1138 \\
\hline $\mathrm{O}_{2}$ Flow, $\mathrm{lb} / \mathrm{hr}$ & - & - & - & 194 & 188 & 182 & - \\
\hline Steam Flow, lb/hr & 120 & 120 & 115 & 220 & 227 & 227 & 118 \\
\hline $\begin{array}{l}\text { Steam:maf }{ }^{1} \text { Coal, } \\
\text { lb/lb }\end{array}$ & 0.52 & 0.50 & 0.39 & 0.82 & 0.85 & 0.83 & 0.37 \\
\hline $\mathrm{O}_{2}:$ maf Coal, lb/lb & 1.17 & 0.99 & 0.78 & 0.82 & 0.92 & 0.87 & 0.82 \\
\hline $\begin{array}{l}\text { Carbon Conversion } \\
\text { (solids) }\end{array}$ & 93.3 & 93.4 & 95.0 & 93.9 & 97.0 & 97.2 & 94.6 \\
\hline \multicolumn{8}{|c|}{ TRDU Product Gas Composition, vol\% } \\
\hline $\mathrm{H}_{2}$ & 6.0 & 8.2 & 6.3 & 11.5 & 13.3 & 12.2 & 7.8 \\
\hline $\mathrm{CO}$ & 6.1 & 8.5 & 5.4 & 6.9 & 9.6 & 8.4 & 8.1 \\
\hline $\mathrm{CH}_{4}$ & 2.2 & 1.6 & 1.7 & 3.0 & 2.9 & 2.5 & 1.9 \\
\hline $\mathrm{CO}_{2}$ & 11.2 & 12.9 & 11.9 & 19.0 & 19.5 & 19.3 & 12.2 \\
\hline $\mathrm{N}_{2}$ & 75.1 & 68.9 & 75.1 & 60.1 & 55.0 & 57.9 & 68.1 \\
\hline Total & 100.6 & 100.1 & 100.4 & 100.4 & 100.3 & 100.4 & 98.1 \\
\hline $\begin{array}{l}\text { Heating Value, } \\
\text { Btu/scf }\end{array}$ & 61.0 & 70.0 & 55 & 90 & 104 & 92.0 & 71 \\
\hline$\% \mathrm{~N}_{2}$ in Dry Feed & 33.5 & 28.7 & 38.8 & 68.9 & 55.1 & 55.8 & 29.4 \\
\hline $\begin{array}{l}\mathrm{N}_{2} \text {-Free Heating } \\
\text { Value, Btu/scf }\end{array}$ & 92.0 & 98.0 & 55 & 199 & 204 & 191 & 103 \\
\hline \multicolumn{8}{|c|}{ Corrected TRDU Product Gas Composition (dry gas, no theoretical heat losses), vol\% } \\
\hline $\mathrm{H}_{2}$ & 13.7 & 16.2 & 14.6 & 31.2 & 32.2 & 31.5 & 16.1 \\
\hline $\mathrm{CO}$ & 13.9 & 16.8 & 12.6 & 18.6 & 23.2 & 21.7 & 16.8 \\
\hline $\mathrm{CH}_{4}$ & 5.0 & 3.2 & 4.0 & 8.1 & 7.0 & 6.6 & 3.9 \\
\hline $\mathrm{CO}_{2}$ & 16.1 & 17.2 & 18.6 & 29.0 & 24.1 & 24.8 & 17.3 \\
\hline $\mathrm{N}_{2}$ & 51.2 & 46.6 & 50.2 & 13.2 & 13.5 & 15.5 & 45.9 \\
\hline Total & 99.9 & 100.0 & 100.0 & 100 & 100.0 & 100.0 & 100.0 \\
\hline $\begin{array}{l}\text { Heating Value, } \\
\text { Btu/scf }\end{array}$ & 140 & 139 & 120 & 243 & 250 & 238 & 146 \\
\hline
\end{tabular}

${ }^{1}$ Moisture and ash-free.

\section{HGFV Operation}

Operation of the HGFV during the gasification tests reported here utilized ten 1.5-m Pall Advanced Separation iron aluminide candle filters. The HGFV was operated between $280^{\circ}$ and $348^{\circ} \mathrm{C}\left(536^{\circ}\right.$ and $\left.658^{\circ} \mathrm{F}\right)$ at a face velocity of approximately $3.3-4.5 \mathrm{ft} / \mathrm{min}$. Backpulse operating parameters were approximately 300 psig backpulse reservoir pressure, with a 0.5 -second opening time. The particulate loading going into the HGFV ranged from approximately 900 to $2000 \mathrm{ppm}$, with a d50 between 6 and $15 \mu \mathrm{m}$. 
Table 5. Best-Case Gasification Operating Conditions

\begin{tabular}{|c|c|c|}
\hline Test & $\begin{array}{l}\text { PRB-Wd } \\
\mathrm{O}_{2} \text {-Blown } \\
\end{array}$ & $\begin{array}{l}\text { PRB-SG } \\
\mathrm{O}_{2} \text {-Blown }\end{array}$ \\
\hline Transport Gas & Air & Air \\
\hline Gasifier Temp., ${ }^{\circ} \mathrm{C}$ & 894 & 918 \\
\hline Feedstock Feed Rate & 521 & 376 \\
\hline Airflow, lb/hr & 253 & 248 \\
\hline $\mathrm{O}_{2}$ Flow, $\mathrm{lb} / \mathrm{hr}$ & 211 & 182 \\
\hline Steam Flow, lb/hr & 228 & 227 \\
\hline Steam:maf Coal, lb/lb & 0.63 & 0.83 \\
\hline $\mathrm{O}_{2}:$ maf Coal, lb/lb & 0.75 & 0.87 \\
\hline Carbon Conversion (solids) & 94.8 & 97.2 \\
\hline \multicolumn{3}{|c|}{ TRDU Product Gas Composition, vol\% } \\
\hline $\mathrm{H}_{2}$ & 14.4 & 12.2 \\
\hline $\mathrm{CO}$ & 9.8 & 8.4 \\
\hline $\mathrm{CH}_{4}$ & 3.5 & 2.5 \\
\hline $\mathrm{CO}_{2}$ & 19.5 & 19.3 \\
\hline $\mathrm{N}_{2}$ & 53.1 & 57.9 \\
\hline Total & 100.3 & 100.4 \\
\hline Heating Value, Btu/scf & 114 & 92.0 \\
\hline$\% \mathrm{~N}_{2}$ in Dry Feed & 54.1 & 55.8 \\
\hline $\mathrm{N}_{2}$-Free Heating Value, Btu/scf & 223 & 191 \\
\hline \multicolumn{3}{|c|}{$\begin{array}{l}\text { Corrected TRDU Product Gas Composition (dry gas, no theoretic } \\
\text { heat losses) vol\% }\end{array}$} \\
\hline $\mathrm{H}_{2}$ & 32.2 & 31.5 \\
\hline $\mathrm{CO}$ & 21.9 & 21.7 \\
\hline $\mathrm{CH}_{4}$ & 7.8 & 6.6 \\
\hline $\mathrm{CO}_{2}$ & 29.5 & 24.8 \\
\hline $\mathrm{N}_{2}$ & 8.4 & 15.5 \\
\hline Total & 100.0 & 100.0 \\
\hline Heating Value, Btu/scf & 255 & 238 \\
\hline
\end{tabular}

During the previous PRB testing, the differences in size distribution for the HGFV samples corresponded to the level of carbon in each sample, with the lowest carbon $(40 \%)$ having the smallest d50, while the highest carbon content (53\%) had the highest d50. Figure 3 shows the particle-size distribution for these samples as well as the samples of the circulating bed material (standpipe) ash. This figure shows that the circulating bed material was fairly consistent in size, with a d50 of about $200 \mu \mathrm{m}$ and a total range of about 100 to $600 \mu \mathrm{m}$. Testing with the PRBbiomass mixtures resulted in no association between carbon content and d50. However, Figure 3 shows that PRB-wood filter vessel particles ranged from 1 to $70 \mu \mathrm{m}$, with a d50 of 7-8 $\mu \mathrm{m}$; PRB-switchgrass filter vessel particles ranged from 1 to $105 \mu \mathrm{m}$, with a d50 of $10 \mu \mathrm{m}$. For PRB-wood tests, standpipe particles ranged from 75 to $850 \mu \mathrm{m}$, with a d50 of approximately $130 \mu \mathrm{m}$. PRB-switchgrass tests produced standpipe particles with the same range, but a d50 of approximately $110 \mu \mathrm{m}$. 


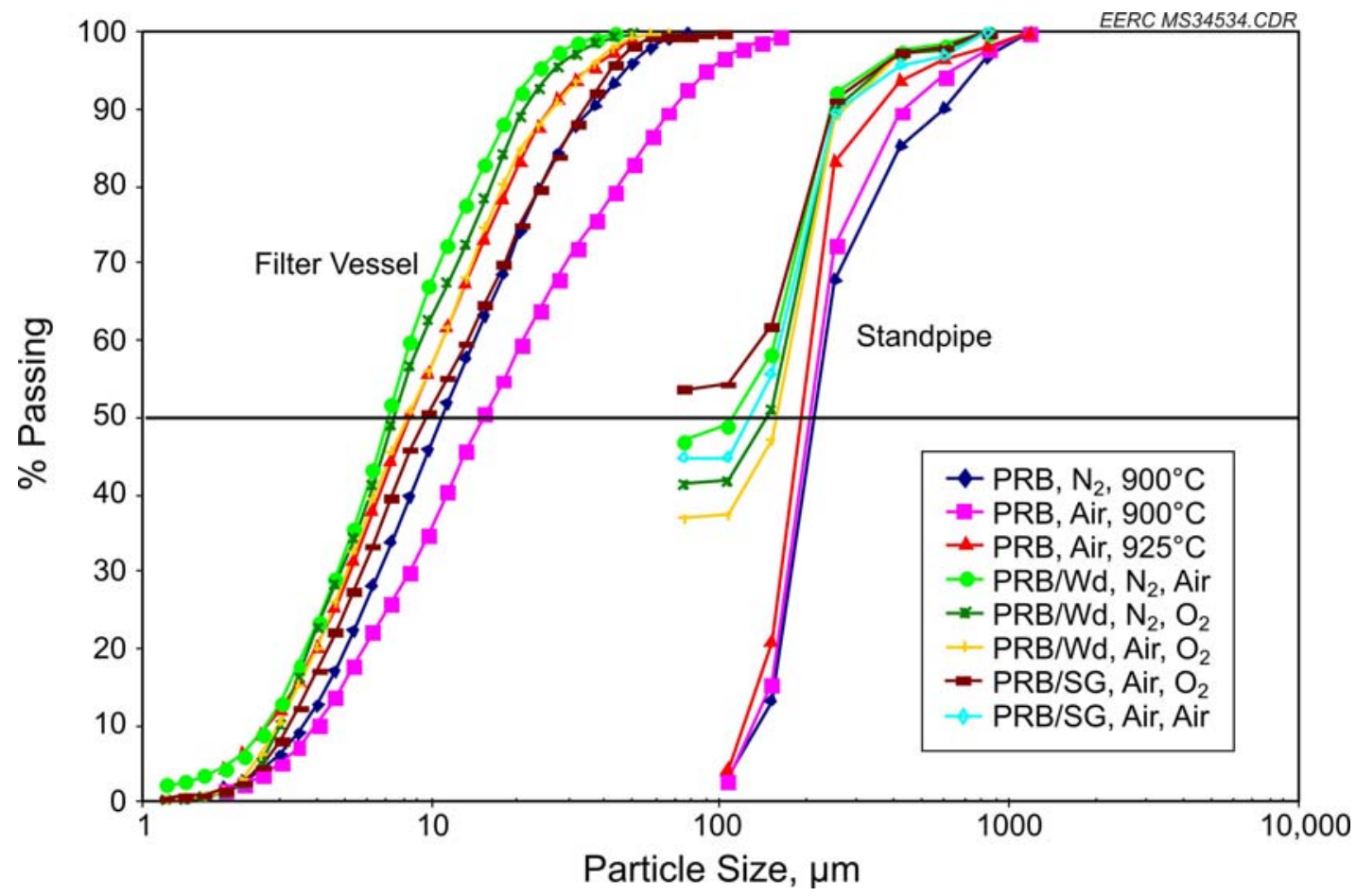

Figure 3. Particle-size distribution for filter vessel and standpipe samples collected during PRB and PRB-biomass testing.

No substantial increase in the "cleaned" filter baseline was observed in these tests. Filter baseline pressure drop was nominally 40-50 in. of water, with candles being backpulsed when an 80 -in. pressure drop was reached. The filter ash ranged from $13-47 \mathrm{wt} \%$ carbon, with a range of $28-57 \mathrm{wt} \%$ carbon for the previous PRB coal tests. In gasification mode, the pulse frequency for these tests was similar to the typically short backpulses seen with other coals, with pulses occurring every 3 to 10 minutes.

Table 6 shows ash analyses for samples taken at the end of each operating condition. Typically, the sand will diminish over time, and the standpipe material composition will more closely resemble that of the coal ash; however, the silica remained high during the entire week of testing. This is because each riser sample removed up to 45 pounds of solids from the system, and fresh sand was added to maintain an adequate solids inventory in the system. The filter ash seems to be very representative of the coal ash plus the small amount of dolomite being fed into the TRDU. Figure 4 is a comparative histogram showing the ash chemistry data of samples collected from the filter vessel. Figure 5 is a histogram showing the ash chemistry data of samples collected from the standpipe. The standpipe samples possibly show some accumulation of potassium in the bed material with the higher ash and higher potassium switchgrass; however, no agglomeration of any bed material was experienced in these tests. Possibly, with enough operating time, some bed chemistry issues could have started to occur. 
Table 6. XRF Ash Analysis of Standpipe and Filter Vessel Ash Samples

\begin{tabular}{|c|c|c|c|c|c|}
\hline & $\begin{array}{l}\text { PRB-Wd, } \\
\mathrm{N}_{2}{ }^{1}, \mathrm{Air}^{2}\end{array}$ & $\begin{array}{l}\text { PRB-Wd, } \\
\mathrm{N}_{2}{ }^{1}, \mathrm{O}_{2}^{2}\end{array}$ & $\begin{array}{l}\text { PRB-Wd, } \\
\text { Air }^{1}, \mathrm{O}_{2}{ }^{2}\end{array}$ & $\begin{array}{l}\text { PRB-SG, } \\
\text { Air }^{1}, \mathrm{O}_{2}{ }^{2}\end{array}$ & $\begin{array}{l}\text { PRB-SG, } \\
\text { Air }^{1}, \text { Air }^{2}\end{array}$ \\
\hline \multicolumn{6}{|l|}{ Filter Vessel } \\
\hline $\mathrm{Si}$ & 29.86 & 36.01 & 32.84 & 39.39 & 38.99 \\
\hline $\mathrm{Al}$ & 9.01 & 8.66 & 10.28 & 5.97 & 7.76 \\
\hline $\mathrm{Fe}$ & 6.73 & 4.35 & 5.31 & 3.84 & 4.75 \\
\hline $\mathrm{Ti}$ & 0.95 & 0.80 & 0.99 & 0.60 & 0.72 \\
\hline $\mathrm{P}$ & 0.63 & 0.57 & 0.65 & 0.79 & 0.99 \\
\hline $\mathrm{Ca}$ & 37.83 & 34.47 & 35.33 & 32.44 & 29.55 \\
\hline $\mathrm{Mg}$ & 13.54 & 13.59 & 12.99 & 14.11 & 12.78 \\
\hline $\mathrm{Na}$ & 0.76 & 0.78 & 0.71 & 0.55 & 0.60 \\
\hline $\mathrm{K}$ & 0.59 & 0.76 & 0.78 & 2.30 & 3.67 \\
\hline $\mathrm{S}$ & 0.11 & 0.01 & 0.11 & 0.00 & 0.19 \\
\hline \multicolumn{6}{|l|}{ Standpipe } \\
\hline $\mathrm{Si}$ & 88.42 & 91.88 & 90.97 & 89.15 & 84.98 \\
\hline $\mathrm{Al}$ & 2.19 & 2.22 & 2.21 & 3.52 & 4.78 \\
\hline $\mathrm{Fe}$ & 1.33 & 0.97 & 1.36 & 1.37 & 1.57 \\
\hline $\mathrm{Ti}$ & 0.10 & 0.08 & 0.09 & 0.15 & 0.21 \\
\hline $\mathrm{P}$ & 0.24 & 0.13 & 0.20 & 0.14 & 0.16 \\
\hline $\mathrm{Ca}$ & 4.29 & 2.24 & 2.54 & 2.53 & 3.52 \\
\hline $\mathrm{Mg}$ & 2.29 & 1.48 & 1.45 & 1.42 & 1.91 \\
\hline $\mathrm{Na}$ & 0.52 & 0.43 & 0.54 & 0.52 & 0.55 \\
\hline $\mathrm{K}$ & 0.60 & 0.57 & 0.64 & 1.21 & 2.32 \\
\hline $\mathrm{S}$ & 0.00 & 0.00 & 0.00 & 0.00 & 0.00 \\
\hline Feedstocks & \multicolumn{2}{|c|}{ PRB-Wd Feed } & & \multicolumn{2}{|c|}{ PRB-SG Feed } \\
\hline $\mathrm{Si}$ & \multicolumn{2}{|c|}{20.42} & & \multicolumn{2}{|c|}{27.34} \\
\hline $\mathrm{Al}$ & \multicolumn{2}{|c|}{12.20} & & \multicolumn{2}{|c|}{10.50} \\
\hline $\mathrm{Fe}$ & \multicolumn{2}{|c|}{6.46} & & \multicolumn{2}{|c|}{5.60} \\
\hline $\mathrm{Ti}$ & \multicolumn{2}{|c|}{1.19} & & \multicolumn{2}{|c|}{1.03} \\
\hline $\mathrm{P}$ & \multicolumn{2}{|c|}{0.76} & & \multicolumn{2}{|c|}{1.15} \\
\hline $\mathrm{Ca}$ & \multicolumn{2}{|c|}{38.53} & & \multicolumn{2}{|c|}{32.30} \\
\hline $\mathrm{Mg}$ & \multicolumn{2}{|c|}{10.28} & & \multicolumn{2}{|c|}{8.49} \\
\hline $\mathrm{Na}$ & \multicolumn{2}{|c|}{1.36} & & \multicolumn{2}{|c|}{1.05} \\
\hline $\mathrm{K}$ & \multicolumn{2}{|c|}{0.85} & & \multicolumn{2}{|c|}{4.21} \\
\hline $\mathrm{S}$ & \multicolumn{2}{|c|}{7.94} & & \multicolumn{2}{|c|}{8.33} \\
\hline
\end{tabular}

${ }^{1}$ Transport gas.

${ }^{2}$ Operational mode (air-blown or oxygen-blown). 


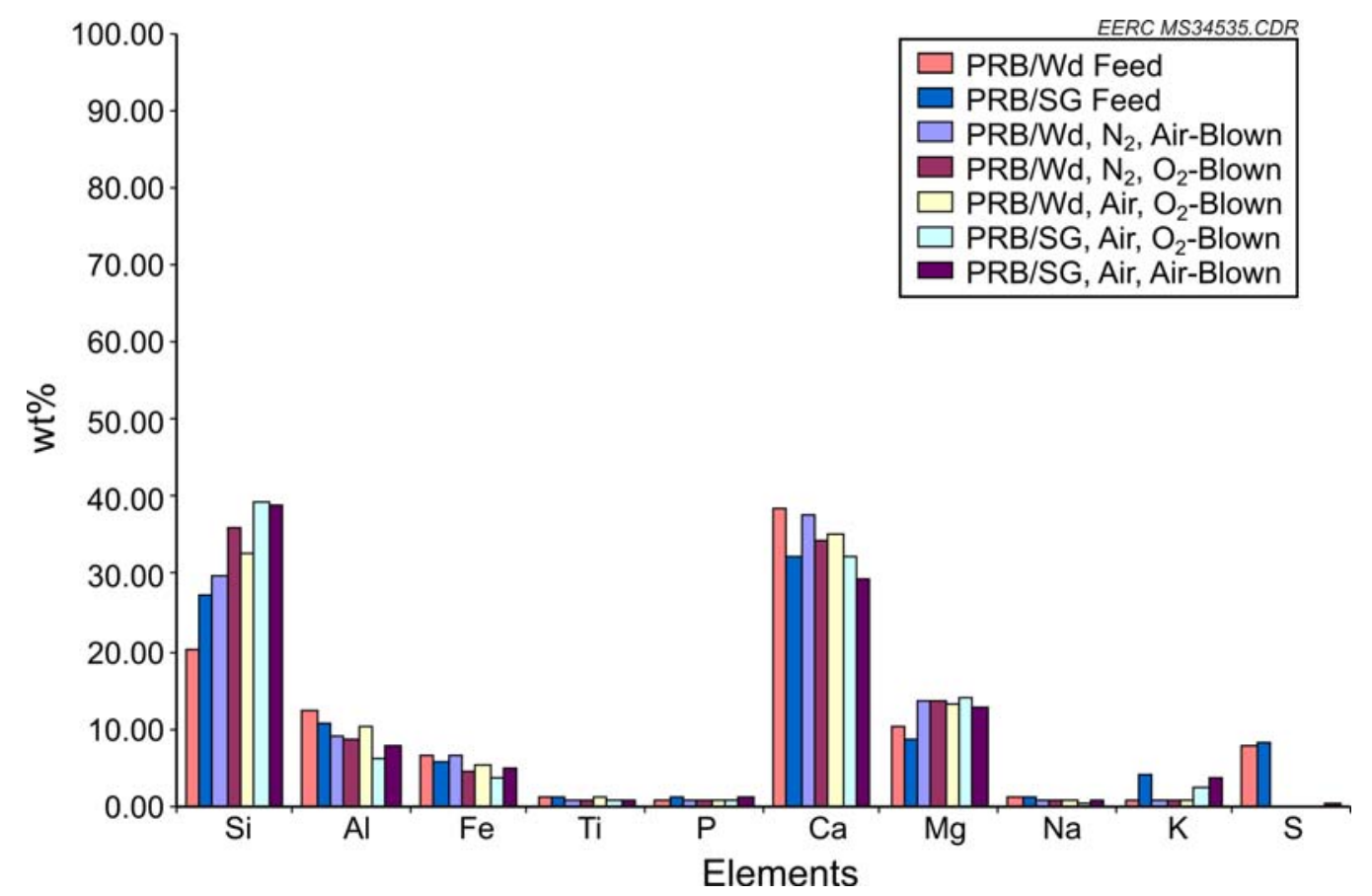

Figure 4. Comparative histogram of ash chemistry data for samples taken at filter vessel.

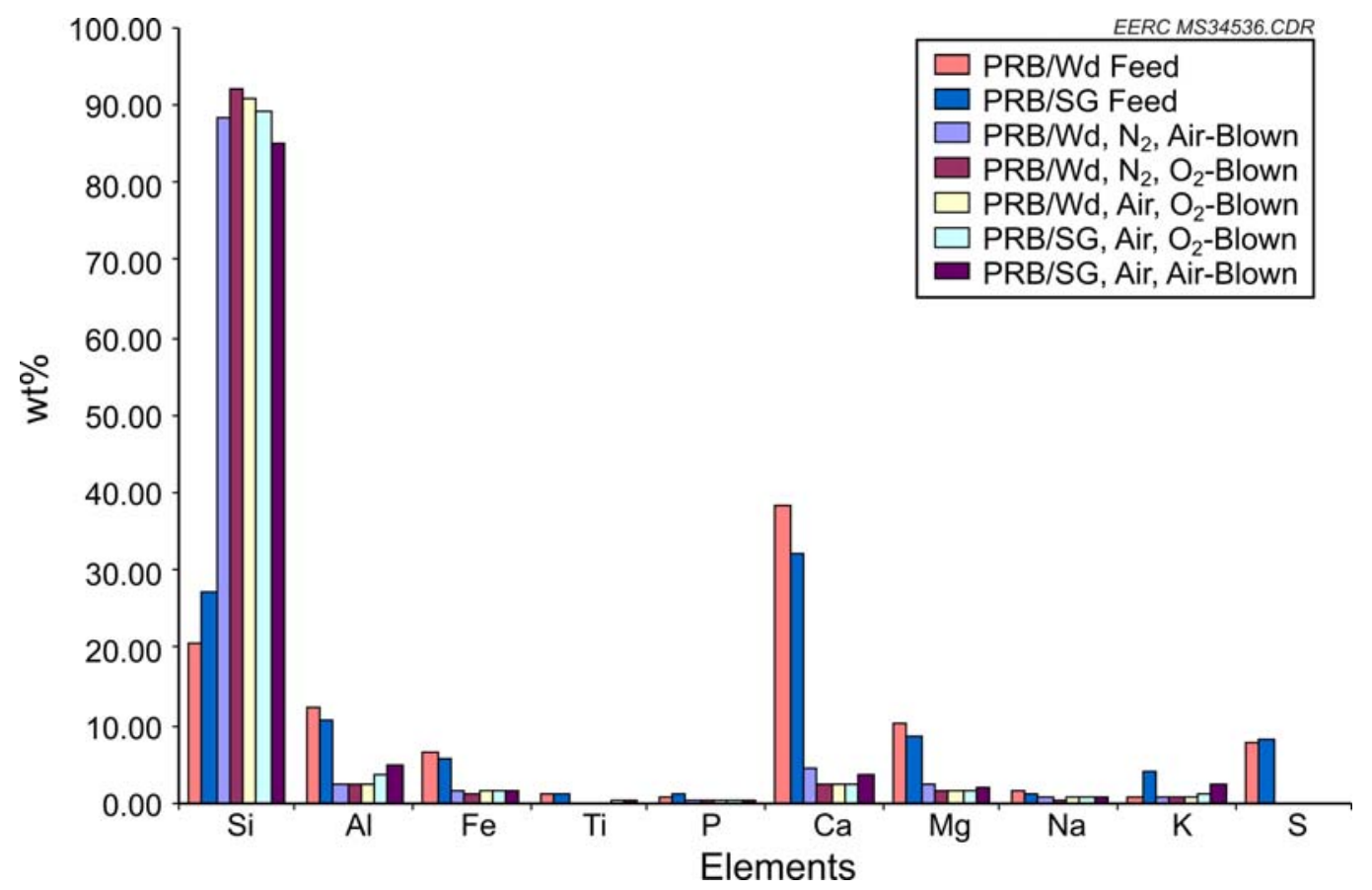

Figure 5. Comparative histogram of ash chemistry data for samples taken from standpipe. 


\section{CONCLUSIONS}

Both wood waste and switchgrass were successfully cofed and gasified in a transport reactor gasifier at an approximately $20 \mathrm{wt} \%$ ratio, resulting in smooth operation with good syngas heating value, high carbon conversion, and no operational issues such as bed agglomeration. Surprisingly few coal-biomass feed trips were encountered during the testing while utilizing the current coal feed system. Initial shakedown testing had suggested that in the 25 to $30 \mathrm{wt} \%$ range coal feed trips would be much more problematic and led to the selection of the $20 \mathrm{wt} \%$ feed ratio. Since the production of FT liquids from coal has a higher carbon footprint than liquid production from petroleum, this successful demonstration testing suggests that cofeeding biomass with coal to reduce the carbon footprint of the FT liquids production plant to below those obtained from a coal-only plant is certainly feasible.

Successful extraction of gas and solids samples from five sample locations in the TRDU was accomplished using a PRB coal and PRB-biomass mixtures. The data suggest very little coal backmixing is occurring in the mixing zone. With increasing residence time, aliphatics concentration decreased, while aromatics concentration increased slightly. Higher gasifier temperatures resulted in lower methane and aliphatics concentrations and higher aromatics concentrations. The sampling also suggests that significantly higher levels of organic species were seen in the lower regions of the riser because of the volatile matter present in the biomass; however, by the exit of the transport reactor, the organic concentrations were very similar between the coal-only tests and the biomass-cofeeding tests.

\section{REFERENCES}

1. Swanson, M.L.; Hajicek, D.R.; Henderson, A.K. Advanced High-Temperature, HighPressure Transport Reactor Gasification. Presented at the 18th Annual Pittsburgh Coal Conference, Newcastle, New South Wales, Australia, Dec 3-7, 2001.

2. Swanson, M.L.; Hajicek, D.R. Advanced High-Temperature, High-Pressure Transport Reactor Gasification. Presented at the 20th Annual Pittsburgh Coal Conference, Pittsburgh, PA, Sept 15-19, 2003. 